\title{
A preliminary leaf epidermal and pollen morphology of some West African species of Desplatsia Bocq
}

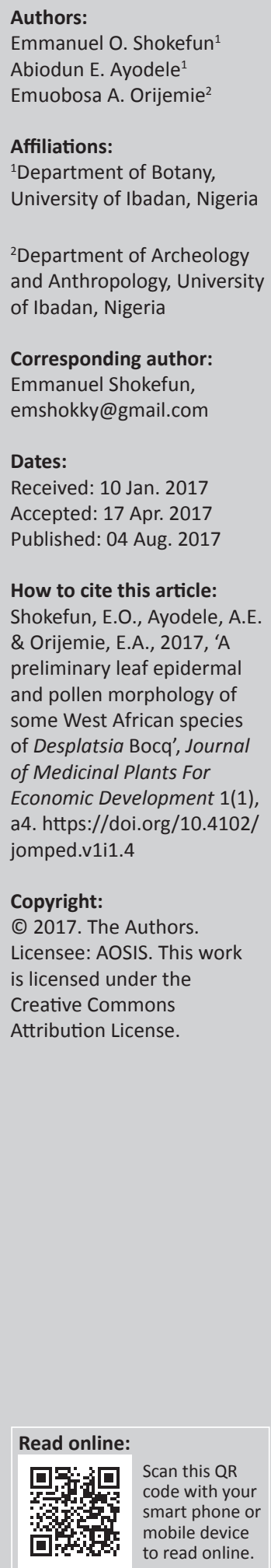

Desplatsia is a genus made up of about four to eight species which are mostly trees native to tropical Africa. The leaf and pollen characters of three West African species of Desplatsia were investigated using light microscopy. The study was aimed at investigating the leaf epidermis and pollen morphology of the species to further enhance the understanding of the taxonomic relationships in the genus. The epidermal cells were isodiametric, polygonal to irregular with straight, curved to wavy anticlinal cell walls. The species were hypostomatic with anisocytic and staurocytic stomata types. The adaxial and abaxial walls of Desplatsia chrysochlamy were characterised by three-celled head multicellular glandular trichomes with highest number of cells and stomata and striated adaxial surface. The four-armed branched and stellate trichomes with the largest stomata size of $19.5 \mu \mathrm{m} \times 15.6 \mu \mathrm{m}$ distinguished $D$. dewevrei from $D$. subericarpa in which the largest cells, lowest number of stomata and size were recorded. The pollen grains were medium in size $26.5 \mu \mathrm{m}-47.5 \mu \mathrm{m}$, tricolporate with long colpi. However, the subprolate, baculate exine surface, small ora and lumen width separated $D$. chrysochlamy from $D$. dewevrei and $D$. subericarpa in which prolate, perforated exine surface and colpi margo were recorded. A key is provided for the identification of the species. Therefore, the ora size, lumen width, number of epidermal cell and stomata are additional taxonomic characters that can be used for species delimitation in the genus.

\section{Introduction}

Desplatsia Bocq. a native to Tropical Africa was first described by Bocquillon in 1867, with a single species Desplatsia subericarpa (Brink 2009). It is made up of four to eight species mostly trees (Bayer \& Kubitzki 2003; Brink 2009; Burret 1926; Hutchinson 1967). The genus is currently placed in the tribe Grewieae in the subfamily Grewioideae alongside Duboscia Bocq., Microcos Linn. and Grewia Linn. in the expanded Malvaceae (Brunken \& Muellner 2012). Many species of the genus occur in bushy places or in cleared or sunny borders of woods in the forest, woodland and savanna habitats while some of the species show a fair amount of adaptability to the surrounding environment (Burkill 2000; Hinsley 2006). The leaf is simple, dentate, serrate but rarely denticulate with persistent, subulately divided stipules. The inflorescence is a $4-10$-flowered cyme with a boat-shaped sepal and very small petals. The large globose to ellipsoid and angular fibrous juicy ripe fruit of Desplatsia species are boiled to obtain a black dye used for cloth and stains like printers ink (Brink 2009). In west tropical Africa, the genus is represented by three species, viz. Desplatsia chrysochlamys (Mildbr. \& Burret) Mildbr. \& Burret., Desplatsia dewevrei (De Wild. \& T. Durand) Burret., and Desplatsia subericarpa Bocq.

Previous systematics of Desplatsia species rest on floral, fruit and a few leaf morphological characters (Burret 1926; Cronquist 1981; Hutchinson \& Dalziel 1954; Masters 1868). The phylogenetic relationship of the genus to other genera in the tribe Grewieae based on molecular data has been reported (Brunken \& Muellner 2012). Anatomical data have provided valuable taxonomic information at the subfamily, tribe, generic and species levels for different groups of plants (Stuessy 2009), including the delimitation of species in the expanded Malvaceae family (Bayer \& Kubitzki 2003). Nonetheless, the taxonomic significance of leaf anatomical features in providing characters of taxonomic value has been exclusively demonstrated by several workers (Carlquist 1961; Metcalfe \& Chalk 1979). Many works have shown that the shape of epidermal cells, types and arrangement of stomata as well as the size, type, distribution and number of cells in trichomes are important taxonomic characters which can be used in delimiting species boundary (Shokefun et al. 2014b; Stace 1984). Also of taxonomic importance is the pollen features which have been utilised over the years in resolving phylogenetic relationship problems (Judd \& Olmstead 2004; Perveen et al. 2004). The present study is, therefore, aimed at investigating the leaf 
epidermis and pollen morphology of the three West African species of Desplatsia.

\section{Materials and methods Source of plant materials}

Fresh plant specimens collected from different localities in Nigeria and herbarium specimens from the Forestry Herbarium Ibadan (FHI) were used for the study. The fresh specimens have been presented in the University of Ibadan Herbarium (UIH). Table 1 gives the list of specimens studied.

\section{Micro morphological study}

\section{Preparation of epidermal peel}

The dried fresh and herbarium leaf specimens of the three species of Desplatsia were first rehydrated by soaking in boiled water for about $20 \mathrm{~min}$ before use. The specimens were cut at the median portions and soaked in concentrated Trioxonitrate (VI) acid for about $8 \mathrm{~h}$, depending on the texture of the leaves according to the procedure described by Ibrahim et al. (2009) The appearance of air bubbles indicated the readiness of the epidermises to be separated. The samples were then transferred to Petri dishes containing water and with the use of fine forceps and dissecting needle the upper and lower epidermal cell surfaces were separated (Ibrahim et al. 2012). These were cleared with camel hair brush in water to remove residual mesophyll layers. The peels were stained with toluidine for 3-5 min, rinsed in water and mounted in glycerol on clean glass slides. The slides were observed and studied using the light microscope. Twentyfive measurements of each of the characters were taken at random. The stomata index (SI) was calculated using the formula (Salisbury 1927) see equation 1.

$$
\mathrm{SI}=\frac{\mathrm{S}}{\mathrm{S}+\mathrm{E}} \times 100 \%
$$

where $\mathrm{S}=$ No. of stomata per unit area;

$\mathrm{E}=$ No. of epidermal cells in the same unit area.

[Eqn 1]

\section{Pollen morphology}

The dried flower and floral buds from herbarium specimens were assessed for pollen morphology using acetolysis method according to Erdtman (1952, 1960), as described by
Shokefun et al. (2014a). The floral buds were crushed in a centrifuge tube. Three millilitres of freshly prepared acetolysis mixture ( 9 parts acetic anhydride to 1 part concentrated Tetraoxosulphate VI acid) was added to the content in the tube. The content was heated in a water bath from $70^{\circ} \mathrm{C}$ to boiling point and stirred occasionally. The centrifuge tubes and content were left in boiling water for 3 min and then centrifuged at $4000 \mathrm{rpm}$. for $5 \mathrm{~min}$ while still hot. The supernatant was decanted, washed with water and centrifuged repeatedly for four times. Fifty per cent glycerin was added and left standing for $2 \mathrm{~h}$. The tubes were shaken vigorously using a whirl mixer and centrifuged at $4000 \mathrm{rpm}$. for $10 \mathrm{~min}$. The supernatant was finally decanted off, and the tube was inverted over filter paper and left overnight. One hundred per cent glycerol was added to the tubes, shaken and poured into labelled storage vials. The pollen grains were mounted in unstained glycerin jelly. The slides were examined with a Fisher Scientific illumination microscope under (E 40; 0.65), oil immersion (E 100; 1.25), using $\times 10$ eye piece. The pollen measurements were based on 20 records from each specimen. Microphotographs were taken using Leica CME with Digital Microscope Eyepiece attachment and Photo Explorer.

\section{Results}

\section{Leaf epidermal surface}

\section{Desplatsia chrysochlamy}

The epidermal cells on the adaxial surface are isodiametric, polygonal to irregular with straight curved to wavy anticlinal walls (Figure 1a). The epidermal cell width was $12.5 \mu \mathrm{m}-$ $20.0 \mu \mathrm{m}$ and the number of epidermal cell count ranges from 480 to 600 per $\mathrm{mm}^{2}$ on the adaxial surface with $2.5 \mu \mathrm{m}-5.0 \mu \mathrm{m}$ cell wall thickness. The adaxial epidermal cells are striated. Stomata and crystals were absent on this surface. Two to three-celled head uniseriate and multicellular glandular trichomes were sparsely distributed on the adaxial surface. Secretory cavities were few on the adaxial surface (Figure 1a). The epidermal cells on the abaxial surface were polygonal to irregular with curved to wavy anticlinal walls (Figure 1b). The cell width was $10.0 \mu \mathrm{m}-12.5 \mu \mathrm{m}$ and the number of epidermal cell count ranges from 378 to 528 per $\mathrm{mm}^{2}$ on the abaxial surface. Uniseriate, two- to three-armed branched trichomes and two- to three-celled head uniseriate glandular

TABLE 1: List of Desplatsia specimens studied.

\begin{tabular}{|c|c|c|c|c|c|}
\hline Serial number & Taxa & Locality & Collectors & Voucher number & Date \\
\hline 1. & Desplatsia chrysochlamy & $\begin{array}{l}\text { Nsuaem, Takoradi, Ghana } \\
\text { De Yapo forest, Abidjan, Ivory Coast }\end{array}$ & $\begin{array}{l}\text { Enti and Agyakwah } \\
\text { Boughey, A.S }\end{array}$ & $\begin{array}{l}\text { FHI } 24525 \\
\text { FHI } 51791\end{array}$ & $\begin{array}{l}19-5-1970 \\
27-7-1954\end{array}$ \\
\hline 2. & Desplatsia dewevrei & $\begin{array}{l}\text { Ibadan, Oyo Nigeria } \\
\text { Okomu, Edo state, Nig } \\
\text { Akure, Ondo state, Nig } \\
\text { ljebu, Ogun state, Nig } \\
\text { Onitsha, Anambra, Nig } \\
\text { Niapidous west, Ivory Coast } \\
\text { Queen Elizabeths forest, Akure, Ondo }\end{array}$ & $\begin{array}{l}\text { A.P.D Jones } \\
\text { Odewo, Olorunfemi, Ariwaodo } \\
\text { R.W.J Keay } \\
\text { Macauley, O } \\
\text { Anetoh, G. } \\
\text { Leeuwenberg, A.J.M } \\
\text { Shokefun, E.O \& Odewo }\end{array}$ & $\begin{array}{l}\text { FHI } 13639 \\
\text { FHI } 101752 \\
\text { FHI } 25494 \\
\text { FHI } 17615 \\
\text { FHI } 36427 \\
\text { FHI } 51453 \\
\text { SEO } 0010\end{array}$ & $\begin{array}{l}22-10-1945 \\
3-7-1984 \\
28-10-1949 \\
20-5-1967 \\
1952 \\
19-2-1959 \\
13-12-2008\end{array}$ \\
\hline
\end{tabular}

FHI, Forestry Herbarium Ibadan; Nig, Nigeria. 

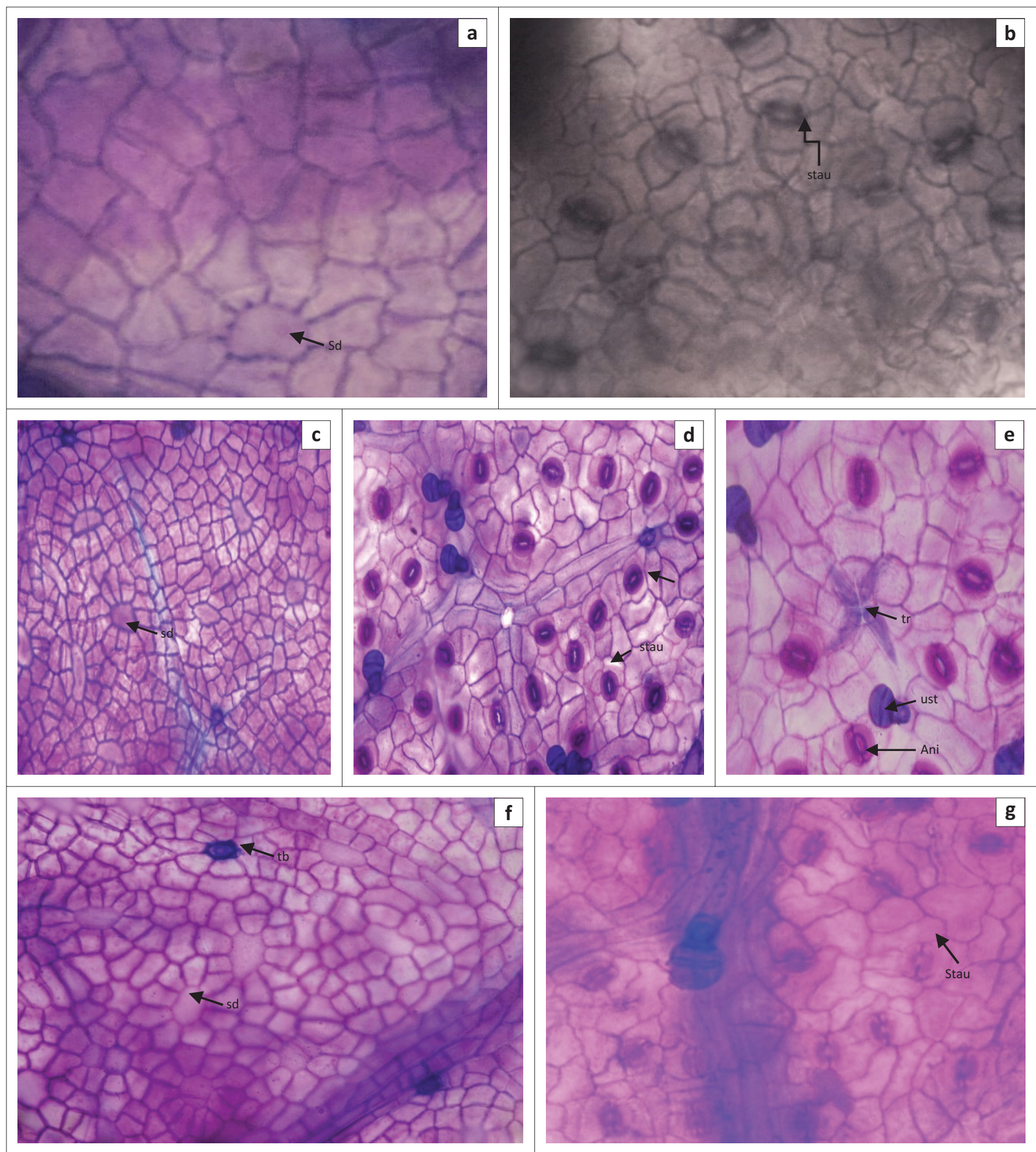

Ani, anisocytic stomata; sd, secretory duct; Stau, staurocytic stomata; tb, trichome base; tr, trichome; ust, uniseriate trichome.

FIGURE 1: Microphotograph of the leaf epidermal surfaces of West African species of Desplatsia. (a) Desplatsia chrysochlamy, Adaxial showing secretory duct, straight, curved and wavy anticlinal cell wall; (b) abaxial surface showing staurocytic stomata, polygonal and irregular epidermal cells (c) D. dewevrei, adaxial surface showing secretory ducts and polygonal or irregular epidermal cells; (d) abaxial surface showing staurocytic stomata and trichome base on veins; (e) Abaxial showing curved to wavy anticlinal walls, 4-armed branched trichome, 2-celled head uniseriate glandular trichomes and anisocytic stomata; (f) D. subericarpa adaxial showing trichome base and secretory ducts; $(\mathrm{g})$ abaxial surface showing staurocytic stomata and uniseriate glandular trichome.

trichomes were recorded on the abaxial surface (Table 2). The species is hypostomatic with anisocytic and staurocytic stomata types (Figure 1b). The stomata size was $15.0 \mu \mathrm{m} \times$ $13.0 \mu \mathrm{m}$ and the SI was $17.2 \%$ while the stomata count per field of view was $101 \mathrm{~mm}^{2}-132 \mathrm{~mm}^{2}$ (Table 3).

\section{Desplatsia dewevrei}

On the adaxial surface, the epidermal cells were largely polygonal to irregular with curved to wavy anticlinal walls (Figure 1c). The epidermal cell width was $7.5 \mu \mathrm{m}-17.5 \mu \mathrm{m}$ while the number of epidermal cells ranged from 314 to 
TABLE 2: Qualitative leaf epidermal characters of some Desplatsia species in West Africa.

\begin{tabular}{|c|c|c|c|c|c|c|c|c|c|c|}
\hline \multirow{2}{*}{$\begin{array}{l}\begin{array}{l}\text { Serial } \\
\text { number }\end{array} \\
1 .\end{array}$} & \multirow{2}{*}{$\begin{array}{l}\text { Taxa } \\
\begin{array}{l}\text { Desplatsia } \\
\text { chrysochlamy }\end{array}\end{array}$} & \multirow{2}{*}{$\begin{array}{l}\text { Cell shape } \\
\text { Adaxial } \\
\text { Isodiametric, } \\
\text { polygonal, } \\
\text { irregular }\end{array}$} & \multirow{2}{*}{$\begin{array}{l}\text { Abaxial } \\
\begin{array}{l}\text { Polygonal, } \\
\text { irregular }\end{array}\end{array}$} & \multirow{2}{*}{$\begin{array}{l}\begin{array}{l}\text { Anticlinal } \\
\text { wall Adaxial }\end{array} \\
\begin{array}{l}\text { Straight, } \\
\text { curve, wavy }\end{array}\end{array}$} & \multirow{2}{*}{$\begin{array}{l}\text { Abaxial } \\
\text { Curve/wavy }\end{array}$} & \multicolumn{2}{|c|}{ Types of trichome } & \multirow{2}{*}{$\begin{array}{l}\text { Type of stomata } \\
\begin{array}{l}\text { Anisocytic, } \\
\text { staurocytic }\end{array}\end{array}$} & \multirow{2}{*}{$\begin{array}{l}\begin{array}{l}\text { Cuticle } \\
\text { ornamentation } \\
\text { Adaxial }\end{array} \\
\text { Striated }\end{array}$} & \multirow{2}{*}{$\begin{array}{l}\text { Abaxial } \\
\text { Not striate }\end{array}$} \\
\hline & & & & & & $\begin{array}{l}2 \& 3 \text {-celled ust \& } \\
\text { mct }\end{array}$ & $\begin{array}{l}\text { 2\&3-armed, } \\
2 \& 3 \text {-celled ust }\end{array}$ & & & \\
\hline 2. & $\begin{array}{l}\text { Desplatsia } \\
\text { dewevrei }\end{array}$ & $\begin{array}{l}\text { Polygonal, } \\
\text { irregular }\end{array}$ & $\begin{array}{l}\text { Polygonal, } \\
\text { irregular }\end{array}$ & Curve, wavy & Curve/wavy & $\begin{array}{l}\text { S,2\&3-armed, } \\
\text { 2-celled ust }\end{array}$ & $\begin{array}{l}\text { 2\&4-armed, Ss, } \\
\text { 2-celled ust }\end{array}$ & $\begin{array}{l}\text { Anisocytic, } \\
\text { staurocytic }\end{array}$ & Not striated & Not striated \\
\hline 3. & $\begin{array}{l}\text { Desplatsia } \\
\text { subericarpa }\end{array}$ & $\begin{array}{l}\text { Isodiametric, } \\
\text { polygonal }\end{array}$ & Irregular & $\begin{array}{l}\text { Straight, } \\
\text { curve, wavy }\end{array}$ & Wavy & $\begin{array}{l}\text { S, } \\
\text { 2-armed, } \\
\text { 2-celled ust }\end{array}$ & $\begin{array}{l}\text { S, 2-armed, } \\
\text { 2-celled ust }\end{array}$ & $\begin{array}{l}\text { Anisocytic, } \\
\text { staurocytic }\end{array}$ & Not striated & Not striated \\
\hline
\end{tabular}

mct, multicellular glandular trichome; Ss, sessile stellate; ust, uniseriate glandular trichome.

TABLE 3: Quantitative epidermal and stomata characters of some Desplatsia species in West Africa.

\begin{tabular}{|c|c|c|c|c|c|c|c|c|c|c|c|}
\hline \multirow{3}{*}{$\begin{array}{l}\text { Serial } \\
\text { number }\end{array}$} & \multirow[t]{3}{*}{ Taxa } & \multicolumn{6}{|c|}{ Epidermal cells } & \multicolumn{4}{|c|}{ Stomata } \\
\hline & & \multicolumn{2}{|c|}{ Number $/ \mathrm{mm}^{2}$} & \multicolumn{2}{|c|}{ Cell width } & \multicolumn{2}{|c|}{ Thickness $(\mu \mathrm{m})$} & \multirow[t]{2}{*}{ Number $/ \mathrm{mm}^{2}$} & \multicolumn{2}{|c|}{ Size $(\mu \mathrm{m})$} & \multirow{2}{*}{$\underset{\%}{\text { Index }}$} \\
\hline & & Adaxial & Abaxial & Adaxial & Abaxial & Adaxial & Abaxial & & Length & Width & \\
\hline 1. & $\begin{array}{l}\text { Desplatsia } \\
\text { chrysochlamy }\end{array}$ & $\begin{array}{c}480-600 \\
590 \pm 90.0\end{array}$ & $\begin{array}{c}378-528 \\
474 \pm 54.3\end{array}$ & $\begin{array}{c}12.0-20.0 \\
16.8 \pm 1.28\end{array}$ & $\begin{array}{c}10.0-12.5 \\
10.5 \pm 0.40\end{array}$ & $\begin{array}{c}2.5-5.0 \\
4.5 \pm 0.30\end{array}$ & $\begin{array}{c}5.0 \\
5.0 \pm 0.00\end{array}$ & $\begin{array}{c}101-132 \\
119 \pm 11.0\end{array}$ & $\begin{array}{c}15.0-17.5 \\
16.0 \pm 0.02\end{array}$ & $\begin{array}{c}10.0-15.0 \\
13.0 \pm 0.08\end{array}$ & 17.2 \\
\hline 2. & $\begin{array}{l}\text { Desplatsia } \\
\text { dewevrei }\end{array}$ & $\begin{array}{c}314-430 \\
387 \pm 49.1\end{array}$ & $\begin{array}{c}166-194 \\
228 \pm 13.1\end{array}$ & $\begin{array}{c}7.5-17.5 \\
12.1 \pm 13.1\end{array}$ & $\begin{array}{c}10.0-12.5 \\
10.8 \pm 0.05\end{array}$ & $\begin{array}{c}2.5-5.0 \\
4.5 \pm 0.00\end{array}$ & $\begin{array}{c}2.5 \\
2.5 \pm 0.00\end{array}$ & $\begin{array}{c}84-93 \\
89 \pm 13.8\end{array}$ & $\begin{array}{c}17.5-20.0 \\
19.5 \pm 0.50\end{array}$ & $\begin{array}{c}15.0-17.5 \\
15.6 \pm 0.30\end{array}$ & 28.1 \\
\hline 3. & $\begin{array}{l}\text { Desplatsia } \\
\text { subericarpa }\end{array}$ & $\begin{array}{c}289-323 \\
306 \pm 14.8\end{array}$ & $\begin{array}{c}197-210 \\
203 \pm 5.03\end{array}$ & $\begin{array}{c}10.0-25.0 \\
17.5 \pm 2.00\end{array}$ & $\begin{array}{c}10.0-15.0 \\
12.5 \pm 1.00\end{array}$ & $\begin{array}{c}2.5 \\
2.5 \pm 0.00\end{array}$ & $\begin{array}{c}2.5 \\
2.5 \pm 0.00\end{array}$ & $\begin{array}{c}52-77 \\
62 \pm 10.1\end{array}$ & $\begin{array}{c}15.0-17.5 \\
16.3 \pm 0.50\end{array}$ & $\begin{array}{c}10.0-15.5 \\
12.0 \pm 0.83\end{array}$ & 24.3 \\
\hline
\end{tabular}

TABLE 4: Qualitative and quantitative pollen morphological characters of some Desplatsia species in West Africa.

\begin{tabular}{|c|c|c|c|c|c|c|c|c|c|c|c|c|}
\hline \multirow{2}{*}{$\begin{array}{l}\text { Serial } \\
\text { number }\end{array}$} & \multirow[t]{2}{*}{ Taxa } & \multirow{2}{*}{$\begin{array}{l}\text { Pollen } \\
\text { shape }\end{array}$} & \multirow{2}{*}{$\begin{array}{l}\text { Exine } \\
\text { surface }\end{array}$} & \multirow{2}{*}{$\begin{array}{l}\text { Colpi } \\
\text { margo }\end{array}$} & \multirow{2}{*}{$\begin{array}{l}\text { Polar view } \\
\quad(\mu \mathrm{m})\end{array}$} & \multirow{2}{*}{$\begin{array}{c}\text { Equator } \\
\text { view }(\mu \mathrm{m})\end{array}$} & \multirow[t]{2}{*}{ Exine $(\mu \mathrm{m})$} & \multirow{2}{*}{$\begin{array}{c}\text { Colpi } \\
\text { length }(\mu \mathrm{m})\end{array}$} & \multicolumn{2}{|c|}{ Ora size $(\mu \mathrm{m})$} & \multirow{2}{*}{$\begin{array}{l}\text { Lumina } \\
\text { width }(\mu \mathrm{m})\end{array}$} & \multirow[t]{2}{*}{ PA/ED\% } \\
\hline & & & & & & & & & Width & Length & & \\
\hline 1. & $\begin{array}{l}\text { Desplatsia } \\
\text { chrysochlamy }\end{array}$ & Subprolate & Baculate & Absent & $\begin{array}{c}39.0-41.5 \\
40.1 \pm 0.30\end{array}$ & $\begin{array}{c}28.0-35.0 \\
31.2 \pm 0.60\end{array}$ & $\begin{array}{c}1.2-1.8 \\
1.5 \pm 0.60\end{array}$ & $\begin{array}{c}34.0-37.5 \\
35.4 \pm 0.56\end{array}$ & $\begin{array}{c}1.7-2.5 \\
2.1 \pm 0.42\end{array}$ & $\begin{array}{c}4.5-5.2 \\
4.9 \pm 0.19\end{array}$ & $\begin{array}{c}1.8-3.5 \\
2.6 \pm 0.54\end{array}$ & 129 \\
\hline 2. & $\begin{array}{l}\text { Desplatsia } \\
\text { dewevrei }\end{array}$ & Prolate & Perforated & Present & $\begin{array}{c}37.5-41.2 \\
39.5 \pm 0.35\end{array}$ & $\begin{array}{c}26.2-32.5 \\
29.0 \pm 0.10\end{array}$ & $\begin{array}{c}2.5-2.7 \\
2.6 \pm 1.00\end{array}$ & $\begin{array}{c}25.0-35.0 \\
31.7 \pm 0.80\end{array}$ & $\begin{array}{c}3.5-5.0 \\
4.3 \pm 0.25\end{array}$ & $\begin{array}{c}10.0-12.5 \\
11.3 \pm 2.00\end{array}$ & $\begin{array}{c}3.5-5.0 \\
4.3 \pm 1.10\end{array}$ & 136 \\
\hline 3. & $\begin{array}{l}\text { Desplatsia } \\
\text { subericarpa }\end{array}$ & Prolate & Perforated & Present & $\begin{array}{c}37.5-47.5 \\
43.0 \pm 1.60\end{array}$ & $\begin{array}{c}27.5-31.2 \\
29.2 \pm 0.25\end{array}$ & $\begin{array}{c}2.5-3.0 \\
2.8 \pm 0.56\end{array}$ & $\begin{array}{c}30.0-37.5 \\
34.2 \pm 0.69\end{array}$ & $\begin{array}{c}3.7-7.5 \\
5.6 \pm 0.11\end{array}$ & $\begin{array}{c}7.5-10.2 \\
8.9 \pm 1.13\end{array}$ & $\begin{array}{c}2.2-4.3 \\
3.3 \pm 0.87\end{array}$ & 147 \\
\hline
\end{tabular}

430 per $\mathrm{mm}^{2}$ on the adaxial surface and cell wall thickness $2.5 \mu \mathrm{m}-5.0 \mu \mathrm{m}$. Stomata and crystals were absent on this surface. Sparsely distributed two-celled head uniseriate glandular trichomes were present on the surface (Table 2). On the adaxial surface, secretory cavities were present and they are distributed throughout the surface. The shape of the epidermal cells on the abaxial surface is polygonal to irregular with curved to wavy anticlinal walls (Figure 1d). The epidermal cell width was $10.0 \mu \mathrm{m}-12.5 \mu \mathrm{m}$ and the number of epidermal cell ranged from 166 to 194 per $\mathrm{mm}^{2}$ on the abaxial surface. The cell wall was $2.5 \mu \mathrm{m}$ thick. Stellate sessile, two- to four-armed unbranched trichomes and twocelled head uniseriate glandular trichomes were present on the abaxial surface (Figure 1e). The species was hypostomatic with abundant elliptic shaped stomata that were anisocytic and staurocytic (Figure 1d and e). The stomata size was $19.5 \mu \mathrm{m} \times 15.6 \mu \mathrm{m}$ and the SI was $28.1 \%$ while the stomata per field of view was $84 \mathrm{~mm}^{2}-93 \mathrm{~mm}^{2}$ (Table 3).

\section{Desplatsia subericarpa}

Epidermal cells on the adaxial surface were isodiametric or polygonal with straight or curved anticlinal walls (Figure 1f). The cell width was $10.0 \mu \mathrm{m}-25.0 \mu \mathrm{m}$ and the number of epidermal cell ranged from 286 to 323 per $\mathrm{mm}^{2}$ on the adaxial surface and $2.5 \mu \mathrm{m}$ cell wall thickness. Stomata and crystals were absent on this surface. Two-celled head glandular trichomes and trichome bases were sparsely distributed on the adaxial surface (Figure 1f). However, short simple unbranched and two-armed branched trichomes were present on the adaxial midrib. Secretory cavities were found throughout the epidermal cells on the adaxial surface (Figure 1f).
On the abaxial surface, the epidermal cells were irregular with wavy anticlinal walls (Figure $1 \mathrm{~g}$ ). The epidermal cell width was $10.0 \mu \mathrm{m}-12.5 \mu \mathrm{m}$ while the number of epidermal cell ranged from 197 to 210 per $\mathrm{mm}^{2}$ on the abaxial surface with thin cell wall. Simple unbranched trichomes and twocelled head uniseriate glandular trichomes (Figure 1g) were present on the abaxial surface. However, a two-armed branched trichome was sparsely recorded on the abaxial midrib. The species was hypostomatic with anisocytic and staurocytic stomata types (Figure $1 \mathrm{~g}$ ). The stomata size was $16.3 \mu \mathrm{m} \times$ $12.0 \mu \mathrm{m}$ and the SI was $24.3 \%$ while the stomata per field of view was $52 \mathrm{~mm}^{2}-77 \mathrm{~mm}^{2}$ (Table 3 ).

\section{Pollen morphology}

\section{Desplatsia chrysochlamy}

Pollen grains were single, isopolar and subprolate; Polar view 40.1 (39-41.5) $\mu \mathrm{m}$ and Equatorial diameter. 31.2 (28-35) $\mu \mathrm{m}, \mathrm{P} / \mathrm{E}$ ratio: 129 (Table 4). Colpi lack any visible margo; are long $35.4(34-37.5) \mu \mathrm{m}$, wide $(3.7 \mu \mathrm{m}-8.7 \mu \mathrm{m})$ and have blunt and in some cases open ends (Figure $2 \mathrm{a}$ ). Ora are la-longate $1.7 \mu \mathrm{m}-2.5 \mu \mathrm{m}$ wide and $4.5 \mu \mathrm{m}-5.2 \mu \mathrm{m}$ long. Pollen grains are three-colporate (Figure $2 b$ ); exine was comparatively thin $(1.2 \mu \mathrm{m}-2.0 \mu \mathrm{m})$; exine was coarsely reticulate; lumina are wide $(1.8 \mu \mathrm{m}-3.5 \mu \mathrm{m})$ and contain numerous bacules inside them; they are also bordered by numerous bacules forming the mural ridge.

\section{Desplatsia dewevrei}

Pollen grains are single, isopolar and prolate. Polar view 37.5-(39.5)-41.2 $\mu \mathrm{m}$; Equatorial diameter 26.2-(29.0)-32.5 $\mu \mathrm{m}$, 


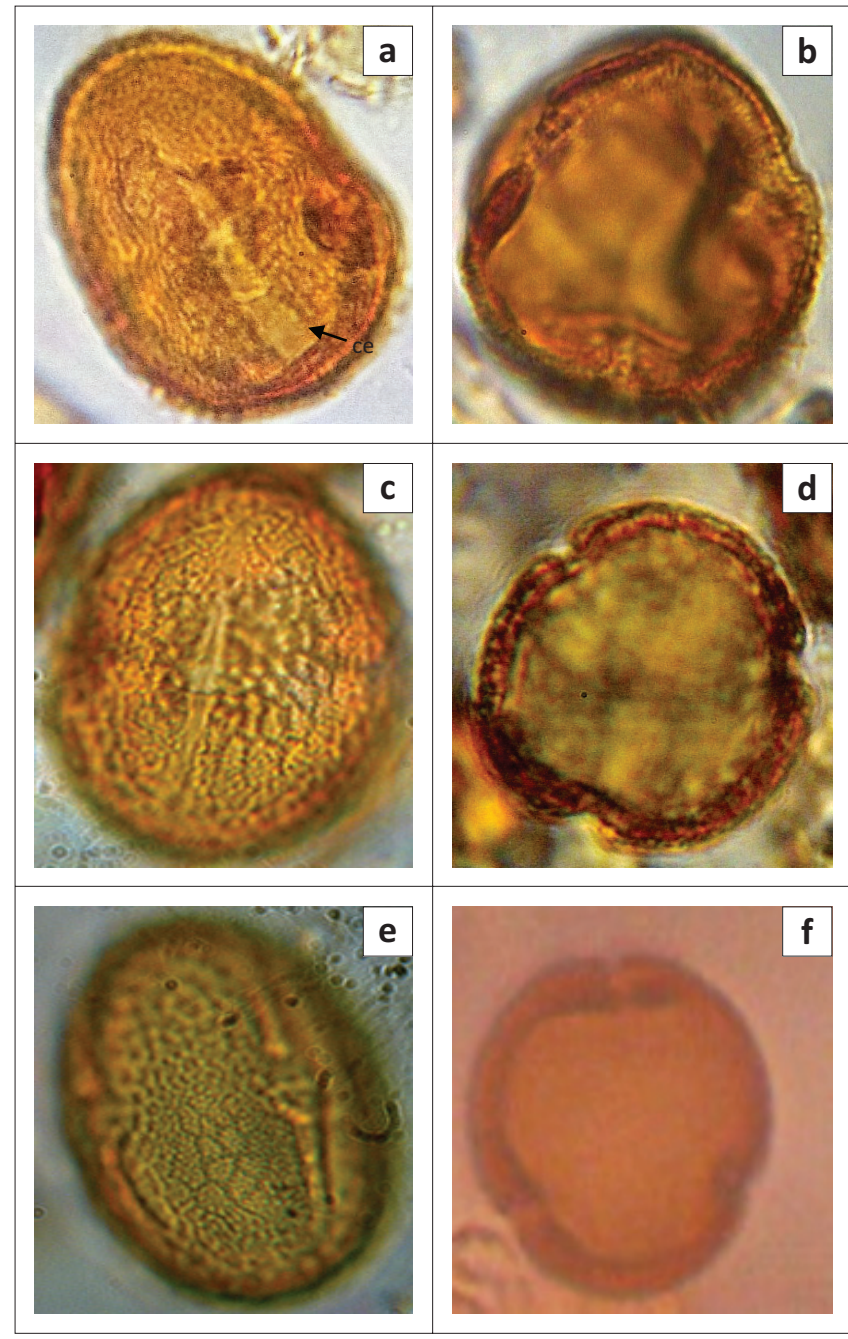

(a)-(b) Desplatsia chrysochlamy equatorial and polar view showing open colpi end and tricolporate grain;

(c)-(d) Desplatsia dewevrei equatorial and polar view showing tricolporate grain;

(e)-(f) Desplatsia subericarpa equatorial and polar view showing tricolporate grain. $\mathrm{Ce}$, Colpi end.

FIGURE 2: Microphotograph of the pollen grains of West African species of Desplatsia.

P/E ratio: 136 (Table 4). Colpi long, narrow with margo (Figure 2c). Ora la-longate, seldom lo-longate; Ora $3.5 \mu \mathrm{m}-$ $5.0 \mu \mathrm{m}$ wide and $10.0 \mu \mathrm{m}-12.5 \mu \mathrm{m}$ long. Pollen grains threecolporate (Figure 2d); exine is $2.5 \mu \mathrm{m}-2.7 \mu \mathrm{m}$ thick; sexine thicker than nexine; exine was very coarsely reticulate, tectum perforated; lumina are large, (3.2 $\mu \mathrm{m}-5.0 \mu \mathrm{m})$, prominent and angular or trapezoid-shaped.

\section{Desplatsia subericarpa}

Pollen grains are single, isopolar and prolate. Polar view 37.5-(43.0)-47.50 $\mu \mathrm{m}$; Equatorial diameter 27.5-(29.2)-31.2 $\mu \mathrm{m}$, P/E ratio: 147. Colpi with margo, long, narrow and taper to the poles (Figure 2e). Ora la-longate, $3.7 \mu \mathrm{m}-7.5 \mu \mathrm{m}$ wide and $7.5 \mu \mathrm{m}-10.3 \mu \mathrm{m}$ long. Pollen grains three-colporate (Figure 2f); exine is $2.5 \mu \mathrm{m}-3.0 \mu \mathrm{m}$ thick; sexine thicker than nexine $(1 \mu \mathrm{m}-1.25 \mu \mathrm{m})$; exine is very coarsely reticulate, tectum perforated; lumina are medium sized $(2.3 \mu \mathrm{m}-4.3 \mu \mathrm{m})$, prominent and angular or trapezoid-shaped with wavy mural ridges. Lumina with more or less same size at mesocolpium; lumina decrease in size towards colpi.

\section{Discussion}

The three West African species of Desplatsia studied are exclusively lowland and are found in the high forest. D. subericarpa is an understory shrub to small tree while $D$. chrysochlamy and $D$. dewevrei are trees. The species have almost similar foliar epidermal characters with only few differences which points to the close inter-relationship among them. On the abaxial surface, epidermal cells are mostly polygonal to irregular with curved and wavy anticlinal walls. On the adaxial surface, isodiametric cell shapes occur in addition to other cell shapes in the taxa of most species except $D$. dewevrei (Figure 1e). The absence of isodiametric cell in $D$. dewevrei distinguished it from other taxa. Adedeji and Jewoola (2008), and Saheed and Illoh (2010) have shown that the varying sizes of foliar epidermal cells in plants could be characteristics and delimiting among closely related species. In this study, the epidermal cell diameter shows overlapping considerably on the abaxial surface and, hence, not taxonomically reliable. However, the lowest epidermal cell diameter on the adaxial surface of $D$. dewevrei is the characteristic of the species. The usefulness of leaf epidermal characters in solving taxonomic problems has been reported by many authors (Ayodele \& Olowokudejo 2006; Kadiri \& Ayodele 2003; Ogundipe \& Ayodele 2000). The highest number of cell $/ \mathrm{mm}^{2}$ and cell thickness on both surfaces separates $D$. chrysochlamy from the others. Variations in the epidermal cells also have been used taxonomically to include features of general epidermal cells, the stomata and trichomes (Bussoti \& Grosson 1997). The hypostomatic nature of the three species of Desplatsia is probably an adaptation to water loss as it is an ecological advantage to survival as perennial plants.

Anisocytic and staurocytic stomata are encountered in the genus and stomata are mostly elliptic in all the species studied (Figure 1a-g). The stomatal size overlaps in $D$. chrysochlamy and D. subericarpa, hence, could only be used with caution. However, the largest stomatal size and highest stomatal index in D. dewevrei and the highest stomatal number and lowest stomatal index in D. chrysochlamy are of taxonomic significance in delimiting both species. D. subericarpa had the lowest number of stomata. Trichomes have been most employed taxonomically to compare species within a genus (Gonzales \& Arbo 2004; Sonibare \& Shokefun 2005; Zarre 2003). In this study, two-celled head glandular trichomes are peculiar to species in the genus. Nevertheless, the presence of three-celled head glandular trichomes and uniseriate branched trichomes as well as absence of simple unbranched trichomes in D. chrysochlamy separate it from the others while the presence of four-armed branched (Figure 1d) and stellate sessile trichomes distinguish $D$. dewevrei from D. subericarpa. The epidermal surfaces were devoid of crystals in all the species while secretory cavities were distributed throughout the epidermis on the adaxial surface. The result of the present investigation obviously shows that foliar epidermal characters could be employed to distinguish between species of Desplatsia. 
Palynological evidence from this work shows similarity in the pollen characters of the taxa studied. The subprolate pollen shape, exine thickness of $1.5 \mu \mathrm{m}$ and absence of margo in the colpi and baculate tectum separated D. chrysochlamy (Figure 2a) from $D$. dewevrei and $D$. subericarpa which have prolate pollen shapes, colpi with margo and perforated tectum (Figure 2c and e). The usefulness of exine ornamentation patterns in the study of systematic and phylogenetic relationships involving subspecies, varieties and cultivars have been reported (Perveen et al. 2004). It must be reiterated, however, that David and Heywood (1963) and Moore et al. (1991) had opined that the shape of pollen grain is less useful taxonomically because it can vary considerably within one species and the variation may be caused by the extracting methods and embedding media used. D. dewevrei and D. subericarpa are only distinguished by the width of their lumen and ora sizes (Table 4); these same characters further separate them from $D$. chrysochlamy. The uniformity of pollen morphological characters observed in $D$. dewevrei and D. subericarpa is an indication of the closer inter-relationship between both species. The pollen characters obtained in this study correlate with the work of Perveen et al. (2004), which reported medium pollen size, tricolporate grains, perforate and coarsely reticulate tectum for the genus. The only deviation from Perveen et al. (2004) in this work is the occurrence of baculate tectum as against perforate tectum reported in D. chrysochlamy. Brunken and Muellner (2012) reported that Desplatsia and Grewia form a well-defined clade based on some morphological and anatomical correlation of molecular genetic clades. However, an additional synapomorphic analysis of the leaf epidermal and pollen grain morphology (comparable to that obtained in this present study) for some representative species of Grewia may be useful in making possible morphotypic discriminations among closely related genera to complement the molecular genetic phyletics. This work has provided basic information on foliar epidermal and pollen characters which could be employed in the identification of the three species of Desplatsia in West Africa. Based on the features observed with the light microscopy, an indented dichotomous key to the species of Desplatsia in West Africa is presented.

\section{Key to the species}

1. Pollen subprolate; tectum non-perforated; exine $1.2 \mu \mathrm{m}-$ $1.8 \mu \mathrm{m}$; colpi margo absent; ora $2.1 \mu \mathrm{m} \times 4.9 \mu \mathrm{m}$; number of adaxial cells $/ \mathrm{mm}^{2}$ 480-600; simple unbranched trichomes absent, glandular trichome head up to threecelled and branche trichomes not more than threearmed...................... chrysochlamy

1. Pollen prolate; tectum perforated; exine $2.5 \mu \mathrm{m}-3.0 \mu \mathrm{m}$; colpi margo present; ora 4.3-5.6 × 8.9-11.3 $\mu \mathrm{m}$; number of cells $/ \mathrm{mm}^{2}$ 289-430; simple unbranched trichomes present, glandular trichome head not more than twocelled and branched trichomes up to four-armed. . . . . .2

2. Ora $4.3 \mu \mathrm{m} \times 11.3 \mu \mathrm{m}$; lumen $4.3 \mu \mathrm{m}$ wide; branched trichomes two to four-armed, stellate trichome present................ dewevrei
2. Ora $5.6 \mu \mathrm{m} \times 8.9 \mu \mathrm{m}$; lumen $3.3 \mu \mathrm{m}$ wide; branched trichomes not more than two-armed, stellate trichome absent. ...................... subericarpa

\section{Conclusion}

This study showed that the ora size, lumen width, epidermal cell and stomatal numbers obtained from both fresh and herbarium specimens of the three species of Desplatsia studied can be used as additional taxonomic characters to delimit species in the genus. However, a molecular study of the genus could further provide a detailed understanding of the phylogeny of the species.

\section{Acknowledgements}

The article was jointly sponsored by all the authors.

\section{Competing interests}

The authors declare that they have no financial or personal relationships which may have inappropriately influenced them in writing this article.

\section{Authors' contributions}

E.O. initiated the project, and A.E. and E.A. are responsible for the project design. E.O. performed the leaf epidermal study. E.A. performed the pollen morphological study and A.E. performed herbarium morphological study and provided back ground information on the genus studied. The result, discussion, conclusion and finance was done by all the authors.

\section{References}

Adedeji, O. \& Jewoola, O.A., 2008, 'Importance of leaf epidermal characters in the Asteraceae family', Notulae Botanicae Horti Agrobotanici Cluj-Napoca 36(2), 7-16.

Ayodele, A.E. \& Olowokudejo, J.D., 2006, 'The family of Polygonaceae in West Africa. Taxonomic significance of leaf epidermal characters', South African Journal of Botany 72, 442-459. https://doi.org/10.1016/j.sajb.2005.12.009

Bayer, C. \& Kubitzki, K., 2003, 'Malvaceae', in K. Kubitzki (ed.), The families and genera of vascular plants, flowering plants, dicotyledons: Malvales, Capparales and non-betalain Caryophyllales, vol. 5, pp. 225-311, Columbia University Press, New York.

Brink, M., 2009, 'Desplatsia subericarpa Bocq', Record from PROTA4U, in M. Brink \& E.G. Achigan-Dako (eds.), PROTA (Plant Resources of Tropical Africa/Ressources végétales de l'Afrique tropicale), Wageningen, Netherlands, viewed 21 July 2015, from http://www.prota4u.org/search.asp

Brunken, U. \& Muellner, A.N., 2012, 'A new tribal classification of Grewioideae (Malvaceae) based on morphological and molecular phylogenetic evidence', Systematic Botany 37, 699-711. https://doi.org/10.1600/036364412X648670

Burkill, H.M., 2006, The useful plants of west tropical, vol. 5, 2nd edn., Royal Botanical Garden, Kew, Richmond, Surrey.

Burret, M., 1926, 'Beitr ge zur kenntnis der Tiliaceae I', Notizblatt des Botanischen Gartens und Museum zu Berlin-Dahlem 9, 592-880. https://doi.org/10.2307/ 3994327

Bussoti, E. \& Grosson, P., 1997, 'European and Mediterranean oaks (Quercus L; Fagaceae): SEM characterization of the micromorphology of the abaxial leaf surface', Botanical Journal of the Linnean Society 124, 183-199. https://doi. org/10.1111/j.1095-8339.1997.tb01789.x

Carlquist, S., 1961, Comparative plant anatomy, Holt, Rinchart and Winston, New York.

Cronquist, A., 1981, An integrated system of classification of flowering plants, Columbia University Press, New York.

David, P.H. \& Heywood, V.H., 1963, Principle of angiosperms taxonomy, Van Nostrand, Princeton, NJ. 
Erdtman, G., 1952, Pollen morphology and plant taxonomy, Chronica Botanica Co, Waltham, MA

Erdtman, G., 1960, 'The acetolysis method: A revised description', Svensk Botanisk Tidskrift 54, 561-564.

Gonzales, A.M. \& Arbo, M.M., 2004, 'Trichome compliment of Turnera and Piriqueto (Turneraceae)', Botanical Journal of the Linnean Society 144, 85-97. https://doi. org/10.1111/j.0024-4074.2004.00229.x

Hinsley, S.R., 2006, Classification of Malvaceae: Overview, composition; position division, Malvaceae Info (Home), viewed 20 December 2011, from http://www. malvaceae.info/Classification/overview.html

Hutchinson, J. \& Dalziel, J.M., 1954, Flora of West tropical Africa, vol. 1, Part 1, 2nd edn., Crown Agents for Overseas Governments Administrations, London.

Hutchinson, J.B., 1967, The genera of flowering plants, vol. 2, pp. 536-567, Clarendon Press, Oxford.

Ibrahim, J.A., Makinde, O. \& Ibekwe, N.N., 2012, 'Pharmacognostic, physicochemical standardization and phytochemical analysis of leaves of cultivated Crotalaria lachnosema Stapf.', Journal of Applied Pharmaceutical Science 2(9), 67-70. https://doi.org/10.7324/japs.2012.2914

Ibrahim, J.A., Okhale, S.E., Jegede, A.I. \& Kunle, O.F., 2009, 'The taxonomy significance of Agelanthus dodoneifolius (DC.) Polh \& Wiens in relations to its hosts', Nigerian Journal of Botany 22(1), 89-101.

Judd, W.S. \& Olmstead, R.G., 2004, 'A survey of tricolpate (eudicot) phylogenetic relationships', American Journal of Botany 91, 1627-1644. https://doi.org/ 10.3732/ajb.91.10.1627

Kadiri, A.B. \& Ayodele, A.E., 2003, 'Comparative leaf micro-morphological characters of the Nigerian species of Rauvolfia Linn. (Apocynaceae)', Bioscience Biotechnology Research Communications 15(6), 35-41.

Masters, M.T., 1868, 'Tiliaceae', Floral Tropical African and British Indian 1, 245-275.

Metcalfe, C.R. \& Chalk, L., 1979, Anatomy of dicotyledons: Systematic anatomy of leaf and stem, with a brief history of the subject, vol. 1, 2nd edn., Clarendon Press, Oxford.
Moore, P.D., Webb, J.A. \& Collinson, M., 1991, Pollen analysis, Blackwell, London.

Ogundipe, O.T. \& Ayodele, A.E., 2000, 'Foliar epidermal characteristics in the genus Brachystegia Benth', Bioscience Biotechnology Research Communications 12(1), $89-85$.

Perveen, A., Grafstrom, E. \& El-Ghazaly, G., 2004, 'World pollen and spore flora 23. Malvaceae, subfamilies: Grewioideae, Tilioideae, Brownlowioideae', Grana 43 , 129. https://doi.org/10.1080/00173130410000730

Saheed, S.A. \& Illoh, H.C., 2010, 'A taxonomic study of some species in Cassinae (leguminosae) using leaf epidermal characters', Notulae Botanicae Hort Agrobotanici Cluj-Napoca 38(1), 21-27.

Salisbury, E.J., 1927, 'On cause and ecological significance of stomata frequency with special reference to woodland flora', Philo Trans Roy Society London Series B 216 , 1-65. https://doi.org/10.1098/rstb.1928.0001

Shokefun, E.O., Orijemie, E.A. \& Ayodele, A.E., 2014a, 'Distribution and pollen morphology of some species of Grewia Linn. in Nigeria', Nigerian Journal of Botany 27(2), 251-263.

Shokefun, E.O., Orijemie, E.A. \& Ayodele, A.E., 2014b, 'Foliar epidermal and pollen characters of some species in the genus Microcos Linn. in Nigeria', American Journal of Plant Sciences 5, 3904-3913. https://doi.org/10.4236/ajps.2014. 526409

Sonibare, M.A. \& Shokefun, E.O., 2005, 'Preliminary leaf epidermal studies of some Ficus species (Moraceae) in Ogun State of South Western Nigeria', African Journal of Pure and Applied Chemistry 1(1), 10-13.

Stace, C.A. 1984, 'The taxonomic importance of the leaf surface', in V.H. Heywood \& D.M. Moore (eds.), Current concepts in plant taxonomy, pp. 67-94, Academy Press, London.

Stuessy, T.F., 2009, Plant taxonomy: The systematic evolution of comparative data, 2nd edn., Columbia University Press, New York.

Zarre, S., 2003, 'Hair micromorphology and its phylogenetic application in thorny species of Astragalus (Fabaceae)', Botanical Journal of the Linnean Society 143 323-330. https://doi.org/10.1046/j.1095-8339.2003.00220.x 